\title{
What does a Project Manager Need to Know about Soft Skills?
}

\author{
Jinzhao Tian \\ The University of Manchester, Manchester, United Kingdom \\ Email: tianjinzhaoricky@163.com
}

\begin{abstract}
In the face of ever-increasing globalisation, the question of how to manage project teams efficiently and successfully was never likely to be settled easily. It has been shown that $92 \%$ of project team members believe that soft skills are needed in their teamwork; $60 \%$ think that soft skills impact project management; $83 \%$ hold the view that soft skills are relevant to the performance of project teams. The research aims to help overseas project managers to obtain greater insight into the impact of soft skills on project teams and so manage them more effectively. The introduction context presents the general concepts of soft skills and project management. Through a wide range of cases and examples of project teams, the impact of those skills on project teams will be explored.
\end{abstract}

Keywords: soft skills, project management, professional competence

\section{Introduction}

The rising trend of project management academic maturation indicates that modern project managers need to acquire a large amount of solid soft skills. This report demonstrates the meaning of 'professional competence' as a high level educated or special trained ability and one of the umbrella terms. So-called soft skills belong to abilities to collaborate with co-workers. This essay collects the published data as well as literature from academic journals and monographs. Although different occupations may have different soft skills, there are still many commonalities among the top few skills. It argues that to be a successful project manager, competence must be acquired, and shows the knowledge of the definition of soft skills, the importance of soft skills and the development of a specific soft skill. Section Two focuses on the meaning of relevant terms; Section Three concentrates on the importance of soft skills, and Section Four shows methods to develop interpersonal skills.

\section{Definitions}

Human resource and recruitment departments are implementing the requirements of their applicants for the company and corporation that the candidates not only have solid academic knowledge or hard skills, but also have good soft skills and comprehensive qualities ${ }^{[1]}$. During the recruiting process, whether the hard skills or soft skills are tested. They are all contained in professional competence.

\subsection{Professional competence}

In the early 1970s, an evaluation result of competence was used as a replacement for IQ as well as an evidence of one's working capacity. Competence was defined as "an underlying characteristic of a person including motives, traits, skills, aspects of one's self-image or social role, or a body of knowledge which he or she uses". ${ }^{[4]}$. Competence is knowledge, skills, abilities, or characteristics associated with high performance on a job, such as problem solving, analytical thinking, or leadership. ${ }^{[5]}$ The researchers above may ignore the professional competence can be trained purposefully. Therefore, the professional competence is a high level educated or special trained ability of addressing multiform working issues appropriately and completing the working task with a convincing consequence.

\subsection{Soft skills}

As a complement of professional competence, soft skills are harder to define and evaluate than hard skills. It is said that hard skills are the ability that an individual can acquire a job, while soft skills are the ability that he or she can keep it and promote it to a high level. Rainsbury ${ }^{[9]}$ found that the soft skills of a great project manager can be seen as adapting the company's spirit, animated, and partners, guidance, addressing work-related issues and organizing, innovation and reliability. For the purpose of this essay, soft skills are individuals' abilities to collaborate and get along well with each other such as team work building and communications. 


\section{The importance of soft skills}

\subsection{Why soft skills are so important}

The first reason can be seen in the job market. Soft skills can be related to how much contribution of a staff make. Consequently, company executives prefer to encourage their candidates having more strong soft skills. ${ }^{[10]}$ The modern job market is showing that hard skills are not enough to help people to keep their jobs especially during the right-sizing and cutting positions time in a company. The second causes are involved in the workplace. There is a research disclosed that three quarters of long-range work success rely on soft skills, while only one quarter is attributed to hard skills. Apart from this, there is also a study that uncovered that the proportion of hard skills contribution of a person's achievement is $15 \%$, whereas that of soft skills is $85 \% .{ }^{[10]}$ As a result, human resources and recruitment departments are continuously searching for candidates who are steady and tactful, they rank soft skills as priority in recruiting process. ${ }^{[10]}$ Similarly, Barlow ${ }^{[2]}$ illustrated that 'often projects fail because of a project manager's inability to communicate effectively, work within the organization's culture, motivate the project the project team and make clear and knowledgeable decisions.'

\subsection{Whether some soft skills are more important than others}

In 1991, the education department of The United Kingdom advocated seven common skills which are considered the most important soft skills. They are self-management and self-development, interpersonal skills, communication, problemsolving skills, numeracy, 'applying technology', design and innovation. According to Marcel's study, Barlow [2] presented that 10 soft skills are considered as the most important. They are uprightness, interflow, manners, obligations, interpersonal skills, optimistic, specialists, creativity, collaboration, and job ethic. All of results are based on the study. There was more than a half human resource manager of the questionnaire sample believed that 'integrity' and 'communication' were extremely vital. In excess of three quarters of the volunteers $(84.2 \%)$ thought that 'courtesy' was a really significant ability, and the percentage of 'responsibility' and that of 'interpersonal skills' are $71.9 \%$ and $61.4 \%$ separately also demonstrated that these two skills are extremely crucial ${ }^{[10]}$. Due to a development from a traditional economy to a networking and office economy, 'integrity', 'communication', and 'flexibility' are emphasized more than other soft skills. From IT executives' points of view, the ability to interflow with bosses, colleagues and subordinates, leadership and the ability to cope with 'ambiguity' and variety are ranked top three in the list of importance of soft skills. As for project management field, the most important soft skills are leadership, followed by communication skills and verbal skills. To sum up, although there are many significant differences between different occupations, it is clear to find that communication skills, interpersonal skills and creativity are often ranked top.

\section{Ways to develop a specific soft skill for project managers}

Although hard skills have irreplaceable status in evaluating an applicant, soft skills should be stressed more in the college curriculum so that learners get a better understanding of the importance of soft skills in advance and pave the way for their future careers ${ }^{[6]}$. There are many limitations to teach how to develop soft skills comprehensively. Therefore, this section is going to talk about only one specific soft skill which is interpersonal skills and it can be divided into three aspects and all the following methods can be used in company's training lessons ${ }^{[7]}$.

Firstly, the interpersonal skills are tremendously influenced by the amount of operating time which employees have to interflow with others. At the beginning of the project, in order to build trust and respect, managers need to define the scope or vision of the project and communicate this vision to subordinates ${ }^{[8]}$. This method not only helps them to get on board with the goals of the project but also establishes a good extra avenue of impact for project managers. Otherwise, the senior project managers may complain that they lose formal authority and prestige. When a crisis emerging during the process, project managers need to find approaches to encourage team members, push them, and charge them so that the program sees success ${ }^{[3]}$. Secondly, interpersonal conversational skills are highly needed in modern conference. It is crucial for project managers to acquire the heart of a problem and then point out a relevant and useful implement, in that much more short-circuited meetings emerging in the rush modern life. Aiming to avoid the ineffectiveness of the meeting, project managers have to control the balance of problem-centered and solution-centered aspects of the conversation. Importantly, project managers need to keep both stakeholders and team members happy via negotiation and make sure both sides satisfy and having a win-win consequence is of necessity. Hence it is appropriate to show a good manner when project managers meet somebody who is important. ${ }^{[6]}$ Therefore, this skill requires executives sharing ideas at a right time with right people and being able to distinguish right and wrong. 


\section{Conclusions}

The aim of this essay is to help project managers to know about soft skills. Therefore, this report has demonstrated the definition of professional competences as well as soft skills. Then a wide range of published data has been compared to provide several reasons for the importance of soft skills and achieve an agreement that communication skills, interpersonal skills and creativity are the most important soft skills, while acknowledging that the important soft skills ranking may vary slightly in different fields. Apart from this, the training goals of how to develop interpersonal skills are offered in the fourth part of this report. Though this essay has shown that there are three aspects to train interpersonal skills, it would appear that other methods are still suitable to develop them. If these methods are adopted and project managers are made aware of them, there will be a marked improvement in soft skill training of project managers.

\section{Reference}

[1] Awan, M.H., Ahmed, K., Zulqarnain, W. Impact of Project Manager's Soft Leadership Skills on Project Success. Journal of Poverty, Investment and Development. 2015; 8: 27-46.

[2] Barlow, A., Barlow, C.G., Boddam-Whetham, L., Robinson, B. A rapid assessment of the current status of project management skills in the conservation sector. Journal for Nature Conservation. 2016; 34: 126-132.

[3] Hunt, W.J. Developing top managers: the impact of interpersonal skills training. Journal of management development. 2003; 22(8): 729-752.

[4] Karen, P. Project Management Skills. AAOHN Journal. 1969; 46(8): 391-403.

[5] Levin, P. Successful teamwork for undergraduates and taught postgraduates working on group projects. Maidenhead: Open University Publishing; 2005.

[6] Margerison, C.J. Interpersonal skills-some new approaches. Journal of European Industrial Training. 1998; 12(6): 12 16.

[7] Miriam, L.M., Anderson, L., Boyden, C. "Soft Skills": A Phrase in Search of Meaning. School of library and information science publishing. 2016; 16(1): 71-88.

[8] Pons, D. Relative importance of professional practice and engineering management competencies. European Journal of Engineering Education. 2015; 41(3): 530-547.

[9] Rainsbury, E., Hodges, D., Burchell, N., Lay, M. Ranking Workplace Competencies: Student and Graduate Preceptions. Asia-Pacific Journal of Cooperative Education. 2002; 3(2): 8-18.

[10] Robles, M.M. Executive Perceptions of the Top 10 Soft Skills Needed in Today's Workplace. Business Communication Quarterly. 2012; 75(4): 453-465. 